Scientific article

Volumen 33(1): Artículo 46173, 2022

e-ISSN 2215-3608, doi:10.15517/am.v33i1.46173

https://revistas.ucr.ac.cr/index.php/agromeso/index

\title{
Gypsum and potassium application to acid soils for maize (Zea mays L.) production in La Frailesca, Chiapas, Mexico ${ }^{1}$
}

\section{Aplicación de yeso y potasio a suelos ácidos para producir maíz (Zea mays L.) en La Frailesca, Chiapas, México}

\author{
Armando Tasistro ${ }^{2}$, Robertony Camas-Gómez ${ }^{3}$, Iván Ortiz-Monasterio ${ }^{4}$
}

1 Reception: March $15^{\text {th }}, 2021$. Acceptance: July $14^{\text {th }}, 2021$. These are results from joint Instituto Nacional de Investigaciones Forestales, Agricolas y Pecuarias (INIFAP) / Centro Internacional de Mejoramiento de Maiz y Trigo (CIMMYT), done as part of the MasAgro project in Chiapas, Mexico.

2 Retired Soil Scientist, 1030 Castle Dr., Watkinsville GA 30677, United States. armsabts@protonmail.com (corresponding author; https:// orcid.org/0000-0002-9903-8396).

3 Instituto Nacional de Investigaciones Forestales, Agricolas y Pecuarias (INIFAP), Chiapas downtown Experimental Camp, Integral Watershed Management. Ocozocoautla, Chiapas, Mexico. camas.robertony@inifap.gob.mx (https://orcid.org/0000-0001-7136-8601).

4 Centro Internacional de Mejoramiento de Maiz y Trigo (CIMMYT), Principal Scientist. Plaza Galerias, Col. Veronica Anzures 11305, Ciudad de Mexico, Mexico. i.ortiz-monasterio@cgiar.org (https://orcid.org/0000-0002-2572-3219).

\begin{abstract}
Introduction. Maize (Zea mays L.) production in La Frailesca region, Mexico, is limited by sandy soils, low in potassium $(\mathrm{K})$, and with acidic arable layers and subsoils. There is information on the management of lime but not on amendments that could be used for subsoil acidity - such as gypsum - nor on the interactions between amendments for soil acidity and $\mathrm{K}$ fertilization. Objective. To evaluate the effects of $\mathrm{K}$ and gypsum on maize and on previously limed soils. Materials and methods. The evaluations were conducted in farmers' fields in La Frailesca region, Chiapas (Mexico) in 2016 and 2017. Four gypsum rates $\left(0,1.25,2.5\right.$ and $\left.5 \mathrm{tha}^{-1}\right)$ and four $\mathrm{K}$ rates $(0,60,90$, and $120 \mathrm{~kg} \mathrm{ha}^{-1}$ as $\mathrm{K}_{2} \mathrm{O}$ ) were factorially combined in a randomized block design, with three replicates. In both years, before the beginning of the experiments, dolomitic lime was applied to the experimental area following standard practices. Responses of crop yield, soil exchangeable $\mathrm{K}, \mathrm{Ca}, \mathrm{Mg}$, and $\mathrm{Al}$, and soil $\mathrm{pH}$ were obtained. Results. Maize yields increased with gypsum (stabilizing at 1.25-3.0 $\mathrm{tha}^{-1}$ ), and $\mathrm{K}$ (stabilizing at 70-120 $\mathrm{kg} \mathrm{ha}^{-1}$ of $\mathrm{K}_{2} \mathrm{O}$ ) applications. In soils, $\mathrm{K}$ application increased exchangeable $\mathrm{K}$ content, while gypsum increased exchangeable $\mathrm{Ca}$ content and $\mathrm{pH}$, and decreased exchangeable $\mathrm{Al}$ content. Liming increased $\mathrm{pH}_{\mathrm{Ca}}$ and exchangeable $\mathrm{Ca}$ and $\mathrm{Mg}$ contents, and lowered the exchangeable Al content in the top $7.5 \mathrm{~cm}$ of soil. Conclusion. Soils with exchangeable $\mathrm{K}\left(\leq 0.3 \mathrm{cmol}_{\mathrm{c}} \mathrm{kg}^{-1}\right)$ were responsive to $\mathrm{K}$ fertilization. The positive effects on yields from gypsum were probably linked to a greater Ca supply in the top $7.5 \mathrm{~cm}$. These results are encouraging about the benefits of the combined application of dolomitic lime, gypsum, and $\mathrm{K}$, but longer evaluations are needed to properly determine the effects of gypsum on subsoil acidity.
\end{abstract}

Keywords: soil calcium, dolomitic lime, soil pH, soil potassium. 


\section{Resumen}

Introducción. La producción de maíz (Zea mays L.) en la región de La Frailesca, México, está limitada por suelos arenosos, bajos en $\mathrm{K}$ y con capas arables y subsuelos ácidos. Existe información sobre el manejo de cal, no así de enmiendas como el yeso que servirían para la acidez del subsuelo, ni sobre las interacciones entre tales enmiendas y la fertilización potásica. Objetivo. Evaluar los efectos del K y el yeso en maíz y en suelos previamente encalados. Materiales y métodos. Las evaluaciones se realizaron en campos de agricultores en La Frailesca, Chiapas (México) en 2016 y 2017. Se combinaron factorialmente cuatro dosis de yeso $\left(0,1,25,2,5\right.$ y $\left.5 \mathrm{t} \mathrm{ha}^{-1}\right)$ y cuatro de $\mathrm{K}(0,60$, 90 , y $120 \mathrm{~kg} \mathrm{ha}^{-1}$ como $\mathrm{K}_{2} \mathrm{O}$ ) en un diseño de bloques al azar, con tres repeticiones. En ambos años, antes de iniciar los experimentos, se aplicó cal dolomítica al área experimental con base en las prácticas estándar. Se obtuvieron las respuestas del rendimiento del cultivo, $\mathrm{pH}$ y $\mathrm{K}, \mathrm{Ca}, \mathrm{Mg}$, y $\mathrm{Al}$ intercambiables del suelo. Resultados. El rendimiento del maíz aumentó al aplicar yeso (estabilizándose a 1,25-3,0 t ha-1) y $\mathrm{K}$ (se estabilizó a 70-120 kg ha-1 de $\mathrm{K}_{2} \mathrm{O}$ ). En los suelos, la aplicación de $\mathrm{K}$ aumentó el $\mathrm{K}$ intercambiable, mientras que el yeso aumentó el Ca intercambiable y el $\mathrm{pH}$, y disminuyó el Al intercambiable. El encalado aumentó el $\mathrm{pH}_{\mathrm{Ca}}$ y los contenidos de $\mathrm{Ca}$ y $\mathrm{Mg}$ intercambiables y disminuyó el Al intercambiable en los 7,5 cm superiores. Conclusión. Suelos con K intercambiable $(\leq 0,3 \mathrm{cmol}$ $\mathrm{kg}^{-1}$ ) respondieron al $\mathrm{K}$. Los efectos del yeso sobre los rendimientos estuvieron probablemente relacionados con el aporte de $\mathrm{Ca}$ en los 7,5 cm superiores. Estos resultados indican posibles beneficios de la aplicación combinada de cal dolomítica, yeso y K, pero faltan evaluaciones de los efectos del yeso en la acidez del subsuelo.

Palabras clave: calcio del suelo, cal dolomítica, $\mathrm{pH}$ del suelo, potasio del suelo.

\section{Introduction}

Soil acidity seriously limits agricultural productivity in La Frailesca region of Chiapas (Mexico) (16 $14^{\circ}$ '00'N, $\left.93^{\circ} 16^{\prime} 09^{\prime \prime} \mathrm{W}\right)$. Recently available results from a survey of 236 farms show average $\mathrm{pH}$ of $5.2( \pm 0.9)$, with exchangeable acidity higher than $0.5 \mathrm{cmol}_{\mathrm{c}} \mathrm{kg}^{-1}$ - considered by the authors as a critical limit for plants - in 64 $\%$ of them, and deficient K contents in $58 \%$ of the samples (López-Báez et al., 2019).

Since the mid-1980s producers and agronomists in the region have been using agricultural lime to amend acidity in the plow layer (Buerkert et al., 1990; Hibon et al., 1992). Lime is typically mixed into the soil to maximize its effect, since it has low solubility in water and would otherwise tend to remain in the surface centimeters (Sumner, 1990).

There is evidence that soil acidity in La Frailesca can extend below the plow layer, at depths practically unreachable with available tillage implements (Tasistro \& Camas-Gómez, 2015). However, there is almost no published information about the management of subsoil acidity in this region.

The most commonly used amendment for subsurface soil acidity is gypsum (Shainberg et al., 1989; Sumner, 1990; 1993) due mainly to its potential mobility into the soil. Positive crop responses to gypsum are typically prompted by its readily raising of the concentration of Ca in soil solution (Shainberg et al., 1989) that leads to improvements in Ca availability and eventually to the promotion of root growth in low Ca-acid soils (Van Raij, 2008). Additionally, gypsum can be beneficial by providing $\mathrm{S}$ and/or decreasing the activity of $\mathrm{Al}$ in soil solution by increasing ionic strength and transforming it into less toxic forms (Zoca \& Penn, 2017).

Exploratory experiments conducted In La Frailesca have shown positive effects on maize (Zea mays L.) yield of dolomitic lime, gypsum, and $\mathrm{K}$ in soils with acidity in their plow layer and subsoil (Tasistro \& Camas-Gómez, 2015).

Based on these circumstances, the objective of this study was to evaluate the responses of maize and soils to a range of rates of $\mathrm{K}$ and gypsum in previously limed soils. 


\section{Materials and methods}

\section{Location characterization}

The study was conducted in maize growing in farmers' fields under rainfed conditions (typically from June to October) in two locations (Raquel and Hermilo) in 2016, and two other locations (Edray and Francisco) in 2017, all with acid sandy soils classified as dystrudepts (Soil Survey Staff, 2014), typical of La Frailesca, Chiapas, which had at the beginning of operations the characteristics presented in Table 1. The levels of exchangeable bases ranged between very low and moderately low according to Castellanos-Ramos et al. (2005).

Table 1. Soil characteristics at two depths at the beginning of the studies of the responses of maize (Zea mays L.) and the soils to a range of $\mathrm{K}$ and gypsum rates in previously limed soils, in the Raquel and Hermilo locations in 2016, and Edray and Francisco in 2017. La Frailesca, Mexico.

Cuadro 1. Características a dos profundidades de los suelos al comienzo de los estudios de las respuestas del maíz (Zea mays L.) y los suelos a un rango de dosis de $\mathrm{K}$ y yeso en suelos previamente encalados, en las localidades Raquel y Hermilo en 2016, y Edray y Francisco in 2017. La Frailesca, México.

\begin{tabular}{|c|c|c|c|c|c|c|c|c|c|c|c|}
\hline \multirow[t]{2}{*}{ Year } & \multirow[t]{2}{*}{ Location } & \multirow{2}{*}{$\begin{array}{c}\text { Depth } \\
\text { (cm) }\end{array}$} & \multirow[t]{2}{*}{$\mathrm{pH}_{\mathrm{Ca}}{ }^{1}$} & \multirow[t]{2}{*}{$\mathbf{p H}_{\mathrm{w}}{ }^{2}$} & \multicolumn{5}{|c|}{$\mathrm{cmol}_{\mathrm{c}} \mathrm{kg}^{-1}$} & \multirow[t]{2}{*}{$\mathbf{C a}_{\%}{ }^{4}$} & \multirow[t]{2}{*}{$\mathbf{A} \mathbf{l}_{\%}{ }^{5}$} \\
\hline & & & & & Ca & Mg & $\mathbf{K}$ & Al & ECEC $^{3}$ & & \\
\hline \multirow[t]{4}{*}{2016} & Raquel & $0-15$ & 3.6 & 4.0 & 1.9 & 0.5 & 0.3 & 0.8 & 3.5 & 54 & 23 \\
\hline & & $15-30$ & 3.5 & 4.0 & 2.2 & 0.5 & 0.1 & 1.2 & 4.0 & 55 & 30 \\
\hline & Hermilo & $0-15$ & 3.5 & 4.3 & 0.7 & 0.1 & 0.3 & 0.8 & 1.9 & 37 & 42 \\
\hline & & $15-30$ & 3.4 & 4.0 & 0.7 & 0.1 & 0.3 & 0.9 & 2.0 & 35 & 45 \\
\hline \multirow[t]{4}{*}{2017} & Edray & $0-13$ & $--{ }^{6}$ & 4.4 & 1.0 & 0.2 & 0.2 & 1.4 & 2.8 & 36 & 50 \\
\hline & & $13-27$ & --- & 4.4 & 0.8 & 0.2 & 0.2 & 2.1 & 3.3 & 24 & 64 \\
\hline & Francisco & $0-13$ & --- & 4.8 & 1.9 & 0.6 & 0.2 & 0.6 & 3.3 & 58 & 18 \\
\hline & & $13-27$ & --- & 4.8 & 1.4 & 0.4 & 0.2 & 1.9 & 3.9 & 36 & 49 \\
\hline
\end{tabular}

${ }^{1} \mathrm{pH}_{\mathrm{Ca}}: \mathrm{pH}$ measured in $0.01 \mathrm{M} \mathrm{CaCl}_{2} . / \mathrm{pH}_{\mathrm{Ca}}: \mathrm{pH}$ medido en $0,01 \mathrm{M} \mathrm{CaCl}_{2}$.

${ }^{2} \mathrm{pH}_{\mathrm{w}:} \mathrm{pH}$ measured in water. / $\mathrm{pH}_{\mathrm{w} \cdot \mathrm{pH}} \mathrm{pmedido}$ en agua.

${ }^{3}$ ECEC: exchangeable bases + KCl-extractable aluminum. / ECEC: bases intercambiables + aluminio extraíble con $\mathrm{KCl}$.

${ }^{4} \mathrm{Ca}_{\%}:$ (exchangeable $\left.\mathrm{Ca} / \mathrm{ECEC}\right) * 100 . / \mathrm{Ca}_{\%}:(\mathrm{Ca}$ intercambiable/ ECEC) $* 100$.

${ }^{5} \mathrm{Al}_{\%}:$ (exchangeable $\left.\mathrm{Al} / \mathrm{ECEC}\right) * 100 . / \mathrm{Al}_{\%}:(\mathrm{Al}$ intercambiable/ECEC) $* 100$.

${ }^{6}$ Not determined. / No determinado.

Soil analyses at the end of the maize cropping cycle could only be made in November 2017 (Edray and Francisco sites), using composite samples made from 18 cores obtained from the six central furrows in each plot at two depths (0-7.5 and 7.5-15 cm), including the area where the fertilizer had been band-applied.

The $\mathrm{pH}$ was determined potentiometrically in water $\left(\mathrm{pH}_{\mathrm{w}}\right)$ and in $0.01 \mathrm{M} \mathrm{CaCl}_{2}\left(\mathrm{pH}_{\mathrm{Ca}}\right)$ with a 1:2 soil: water ratio; K, Ca, and $\mathrm{Mg}$, were extracted with ammonium acetate $1 \mathrm{~N} \mathrm{pH} 7$ (Knudsen et al., 1982), and extractable Al with $\mathrm{KCl} 1 \mathrm{~N}$ (Lin \& Coleman, 1960). Effective cation exchange capacity (ECEC) was calculated as the sum of exchangeable bases $+\mathrm{KCl}$-extractable aluminum, while $\mathrm{Al}$ and $\mathrm{Ca}$ saturation (\%) was calculated by dividing exchangeable $\mathrm{Al}$ and $\mathrm{Ca}$ by the ECEC. 
Rainfall in 2016 and 2017 was 1,359 and 1,782 mm, respectively, higher than the historical average for the study area which is $1,115 \mathrm{~mm}$ (Serrano et al., 2006).

\section{Experimental design}

The treatments consisted of a factorial combination of four rates of agricultural gypsum $(0,1.25,2.5$, and 5.0 $\left.\mathrm{t} \mathrm{ha}^{-1}\right)$ and four of $\mathrm{K}\left(0,60,120\right.$, and $180 \mathrm{~kg} \mathrm{ha}^{-1}$ of $\left.\mathrm{K}_{2} \mathrm{O}\right)$, using $\mathrm{KCl}$ as the source, arranged in a randomized block design with three replicates. Each experimental unit had eight rows $6 \mathrm{~m}$ long and $80 \mathrm{~cm}$ apart. The four central rows were harvested manually, excluding $1 \mathrm{~m}$ in the row headers. The grain yield is expressed on a $14 \%$ moisture basis.

The statistical analyses were done with Genstat (VSN International, 2018), using a probability level of $5 \%$ to define the significance of the analyzed effects.

\section{Agronomic practices}

The agricultural gypsum used originated from mines; it was applied manually four to five days before planting, and left on the surface. Two days after sowing, $\mathrm{KCl}$ was applied manually in a band and buried next to the seeds, together with $20 \%$ of the total $\mathrm{N}\left(40 \mathrm{~kg} \mathrm{ha}^{-1}\right.$, as urea) and $100 \%$ of the $\mathrm{P}\left(60 \mathrm{~kg} \mathrm{P}_{2} \mathrm{O}_{5}\right.$ ha $^{-1}$, as triple superphosphate $)$. The remaining $\mathrm{N}$ was side dressed and buried at around $\mathrm{V} 6$, also as urea.

Seven days before sowing all the experimental areas were treated with commercial dolomitic lime following standard practices for the region, which include incorporation using disk harrows to a depth of 10-12 cm.

In 2016, the variety 'V561' was planted in both locations, while in 2017 the hybrids 'DK7500 A' and 'DK390' were used in the locations Edray and Francisco, respectively. In conventionally prepared soil, one seed was sown manually per hole, with an initial density of 65,000 seeds ha $^{-1}$. Seeding dates in both years were within the normal range for the region, and standard agronomic management practices were followed to keep the experiment free of weeds, pests, and diseases.

\section{Results}

In both cropping cycles and all locations, maize yields increased in response to $\mathrm{K}$ and gypsum applications, with no significant interactions between the two factors being detected.

The positive response of maize yields to $\mathrm{K}$ applications (Figure 1) followed a linear-plateau model, showing increasing yields up to $120 \mathrm{~kg} \mathrm{ha}^{-1}$ of $\mathrm{K}_{2} \mathrm{O}$ in three locations, and up to $70 \mathrm{~kg} \mathrm{ha}^{-1}$ of $\mathrm{K}_{2} \mathrm{O}$ in location Hermilo. In locations Raquel, Edray and Francisco, crop response to gypsum followed a linear-plateau model with maximum yield at $1.25 \mathrm{tha}^{-1}$ of gypsum, while in location Hermilo the response was parabolic, with an increase in yield up to $3 \mathrm{t} \mathrm{ha}^{-1}$ of gypsum (Figure 2).

The results of soil analyses at both depths $(0-7.5 \mathrm{~cm}$ and $7.5-15 \mathrm{~cm})$ at the end of the season in 2017 in locations Edray and Francisco, showed that the application of K resulted in significant increases in soil K (Figure 3 ), whereas the application of gypsum brought about increases in exchangeable Ca (Figure 4). However, the decrease in Al saturation, because of gypsum application, was detected only in the upper $7.5 \mathrm{~cm}$ of the soil in location Edray (Figure 5). 


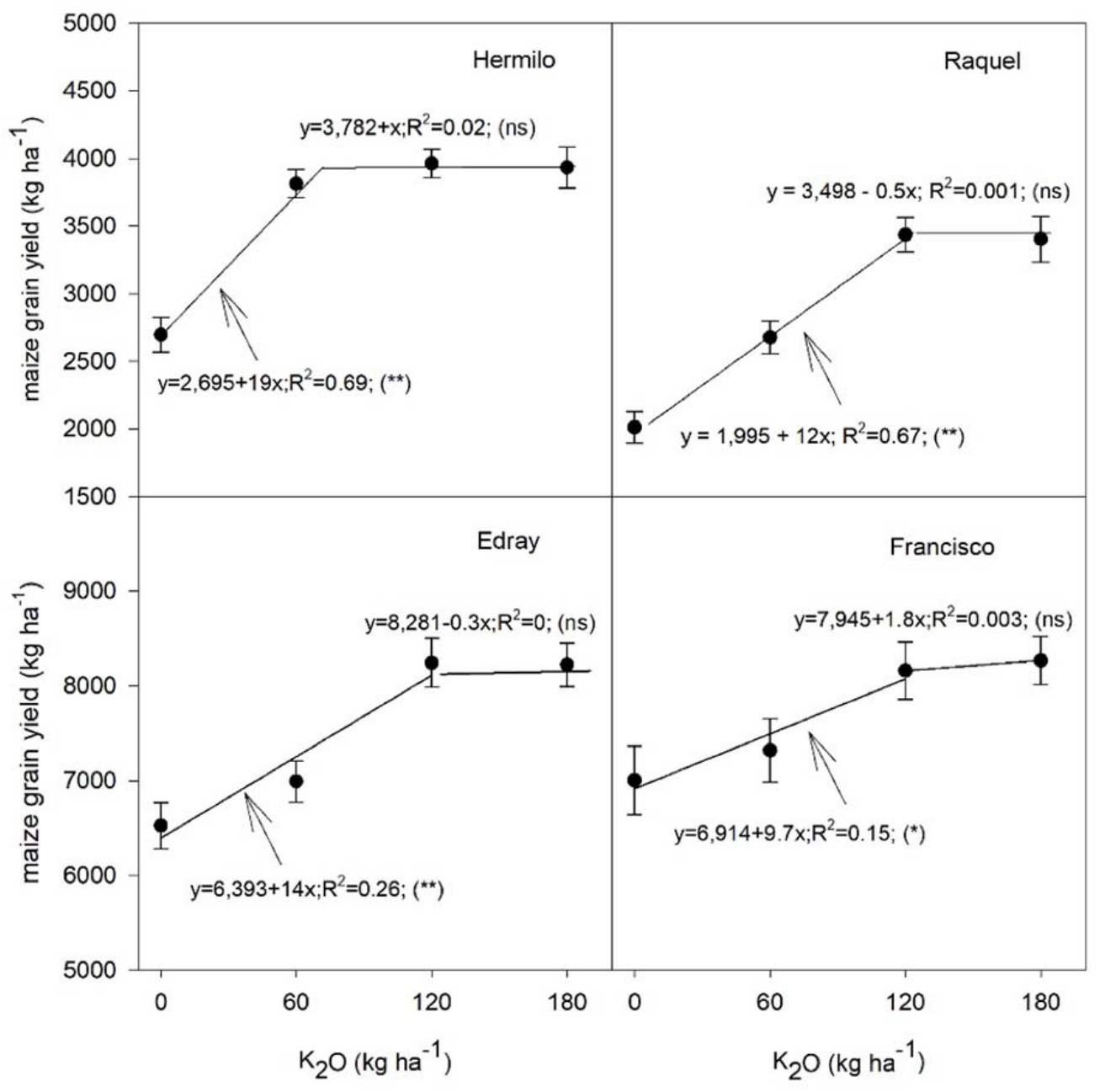

Figure 1. Maize (Zea mays L.) grain yield response to K fertilization in 2016 (Hermilo and Raquel locations) and 2017 (Edray and Francisco locations). Instituto Nacional de Investigaciones Forestales, Agricolas y Pecuarias (INIFAP) / Centro Internacional de Mejoramiento de Maiz y Trigo (CIMMYT). La Frailesca, Mexico.

Bars show standard errors.

Figura 1. Respuesta del rendimiento de grano de maíz (Zea mays L.) a la fertilización potásica en 2016 (localidades Hermilo y Raquel) y 2017 (localidades Edray and Francisco). Instituto Nacional de Investigaciones Forestales, Agricolas y Pecuarias (INIFAP) / Centro Internacional de Mejoramiento de Maíz y Trigo (CIMMYT). La Frailesca, México.

Las barras indican los errores estándar.

In both locations, gypsum increased $\mathrm{pH}_{\mathrm{Ca}}$ at 0-7.5 cm (Figure 6); no effects were detected at 7.5-15 cm, where $\mathrm{pH}_{\mathrm{Ca}}$ averaged 3.6 and 3.8 in Edray and Francisco locations, respectively.

The comparison of the values of some soil properties measured at the $0-7.5 \mathrm{~cm}$ and at the $7.5-15 \mathrm{~cm}$ depth intervals, in soil that did not receive gypsum, allowed an estimation of the effects of the blanket application of 


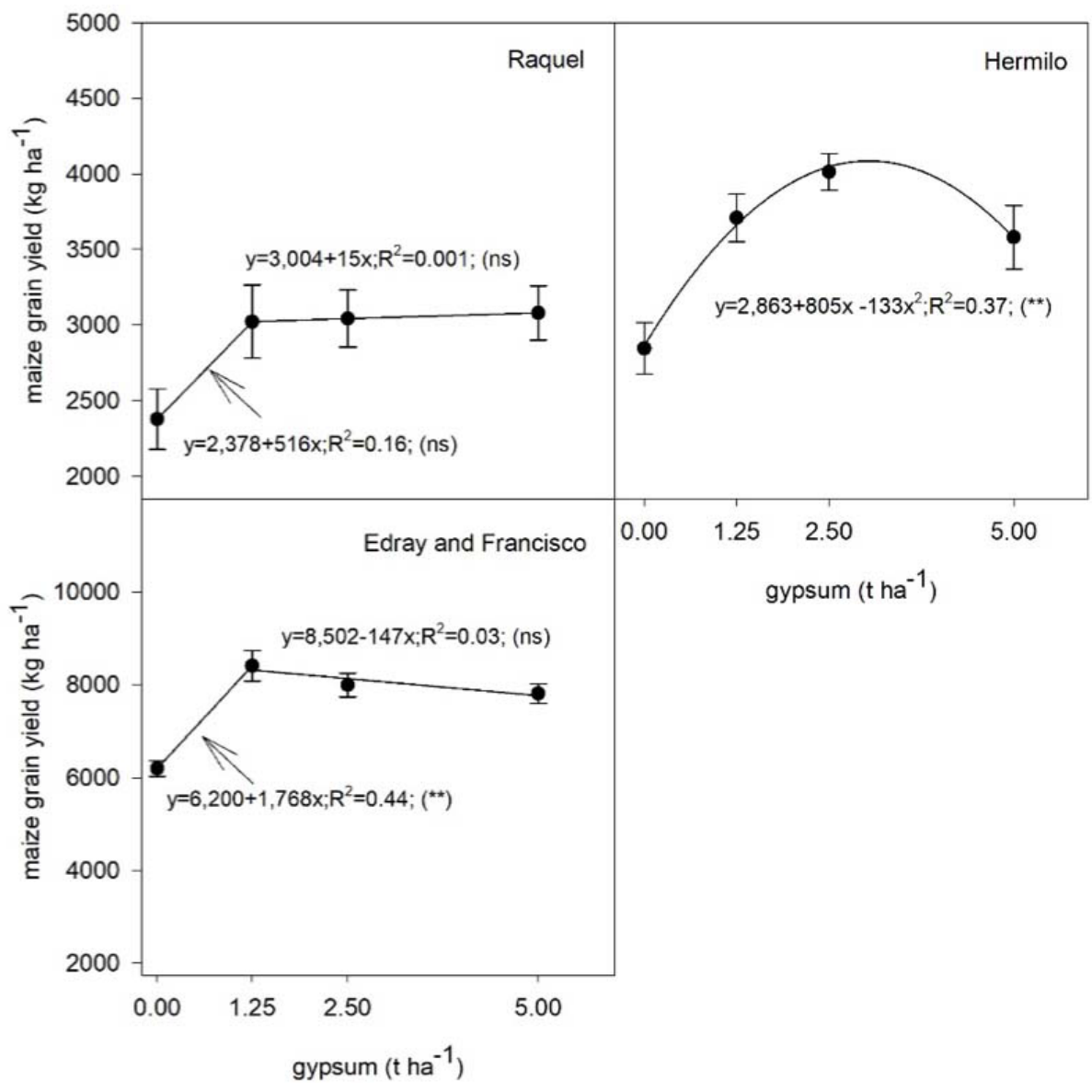

Figure 2. Maize (Zea mays L.) grain yield response to gypsum in 2016 (Hermilo and Raquel locations) and 2017 (Edray and Francisco locations). Instituto Nacional de Investigaciones Forestales, Agricolas y Pecuarias (INIFAP), Centro Internacional de Mejoramiento de Maiz y Trigo (CIMMYT). La Frailesca, Mexico.

The results from the Edray and Francisco locations were combined because they did not differ statistically. Bars show standard errors.

Figura 2. Respuesta del rendimiento de grano de maíz (Zea mays L.) al yeso en 2016 (localidades Hermilo y Raquel) y 2017 (localidades Edray y Francisco). Instituto Nacional de Investigaciones Forestales, Agricolas y Pecuarias (INIFAP), Centro Internacional de Mejoramiento de Maíz y Trigo (CIMMYT), La Frailesca, México.

Los resultados de las localidades Edray y Francisco fueron combinados porque no difirieron estadísticamente entre sí. Las barras muestran los errores estándar.

dolomitic lime made before the beginning of the study. Liming improved the acidity conditions in the top $7.5 \mathrm{~cm}$ of soil by increasing $\mathrm{pH}_{\mathrm{Ca}}$, exchangeable $\mathrm{Ca}$, and $\mathrm{Mg}$ contents, and by lowering $\mathrm{Al}$ content (Table 2). 


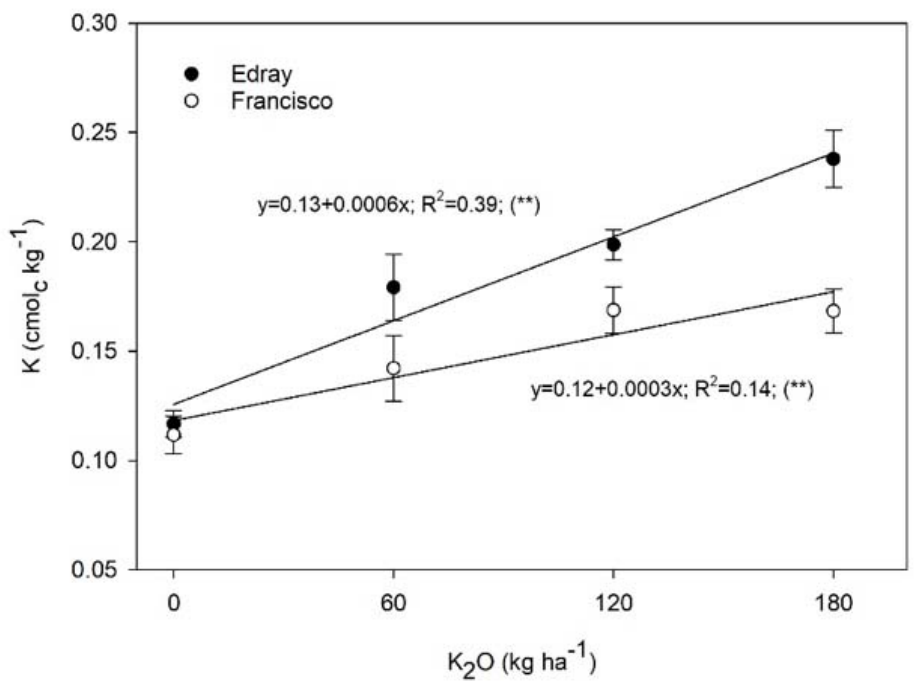

Figure 3. Effect of $\mathrm{K}$ fertilization on the exchangeable K extracted from the soils in the Edray and Francisco locations. Results from 0-7.5 $\mathrm{cm}$ and 7.5-15 cm have been combined because they did not differ statistically. Instituto Nacional de Investigaciones Forestales, Agricolas y Pecuarias (INIFAP), Centro Internacional de Mejoramiento de Maiz y Trigo (CIMMYT). La Frailesca, Mexico, 2017.

Bars show standard errors.

Figura 3. Efecto de la fertilización potásica en el $\mathrm{K}$ intercambiable extraído de los suelos en las localidades Edray and Francisco. Los resultados de 0-7,5 $\mathrm{cm}$ y 7,5-15 $\mathrm{cm}$ fueron combinados porque no difirieron estadísticamente entre sí. Instituto Nacional de Investigaciones Forestales, Agrícolas y Pecuarias (INIFAP), Centro Internacional de Mejoramiento de Maíz y Trigo (CIMMYT). La Frailesca, México, 2017.

Las barras muestran los errores estándar.

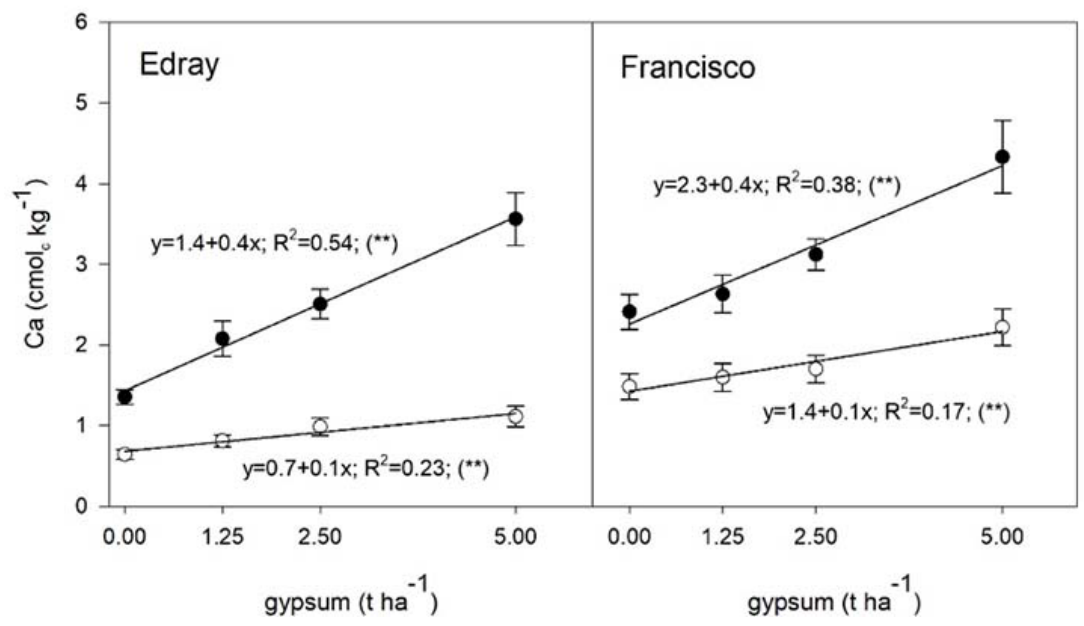

Figure 4. Response of soil exchangeable Ca content to gypsum in $0-7.5 \mathrm{~cm}(\bigcirc)$ and at $7.5-15 \mathrm{~cm}(\mathrm{O})$ soil layers in the Edray and Francisco locations. Instituto Nacional de Investigaciones Forestales, Agricolas y Pecuarias (INIFAP), Centro Internacional de Mejoramiento de Maiz y Trigo (CIMMYT). La Frailesca, Mexico, 2017.

Bars show standard errors.

Figura 4. Respuesta del contenido de Ca intercambiable del suelo al yeso a 0-7,5 cm (O) y a 7,5-15 cm (O) en las localidades Edray y Francisco. Instituto Nacional de Investigaciones Forestales, Agrícolas y Pecuarias (INIFAP), Centro Internacional de Mejoramiento de Maíz y Trigo (CIMMYT). La Frailesca, México, 2017.

Las barras muestran los errores estándar. 


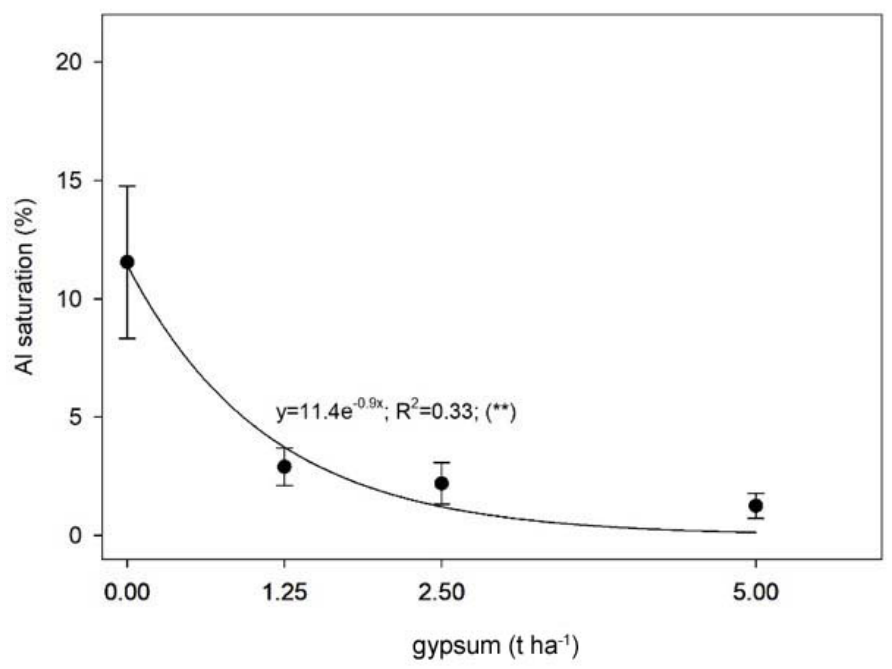

Figure 5. Effect of four rates of gypsum on the percent of $\mathrm{Al}$ saturation at the $0-7.5 \mathrm{~cm}$ soil depth in the Edray location. Instituto Nacional de Investigaciones Forestales, Agricolas y Pecuarias (INIFAP), Centro Internacional de Mejoramiento de Maiz y Trigo (CIMMYT). La Frailesca, Mexico, 2017.

Bars show standard errors.

Figura 5. Efecto de cuatro dosis de yeso sobre el porcentaje de saturación de Al a 0-7,5 cm de profundidad del suelo en la localidad Edray. Instituto Nacional de Investigaciones Forestales, Agrícolas y Pecuarias (INIFAP), Centro Internacional de Mejoramiento de Maíz y Trigo (CIMMYT). La Frailesca, México, 2017.

Las barras muestran los errores estándar.

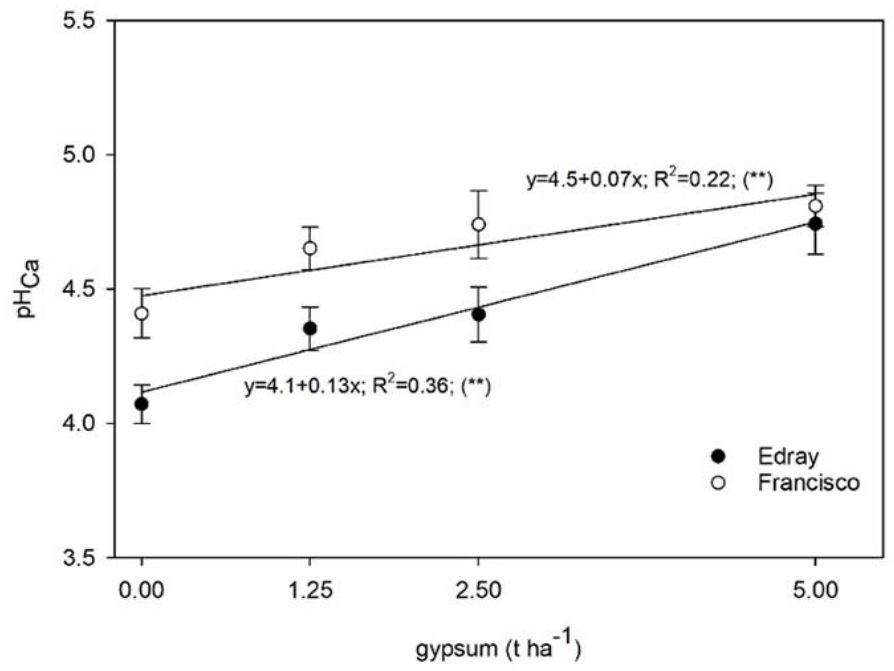

Figure 6. Effect of gypsum on the $\mathrm{pH}_{\mathrm{Ca}}$ in the $0-7.5 \mathrm{~cm}$ of soil in the Edray and Francisco locations. Instituto Nacional de Investigaciones Forestales, Agricolas y Pecuarias (INIFAP), Centro Internacional de Mejoramiento de Maiz y Trigo (CIMMYT). La Frailesca, Mexico, 2017. Bars show standard errors.

Figura 6. Efecto del yeso sobre el $\mathrm{pH}_{\mathrm{Ca}}$ en $\operatorname{los} 0-7,5 \mathrm{~cm}$ del suelo en las localidades Edray y Francisco. Instituto Nacional de Investigaciones Forestales, Agrícolas y Pecuarias (INIFAP), Centro Internacional de Mejoramiento de Maíz y Trigo (CIMMYT). La Frailesca, México, 2017.

Las barras muestran los errores estándar. 
Table 2. Effects of dolomitic lime on $\mathrm{pH}_{\mathrm{Ca}}$ exchangeable, $\mathrm{Ca}$, and $\mathrm{Mg}$, and the saturarion percentage of $\mathrm{Ca}$ and $\mathrm{Al}$ at two soil depths in locations Edray and Francisco. Instituto Nacional de Investigaciones Forestales, Agricolas y Pecuarias (INIFAP), Centro Internacional de Mejoramiento de Maiz y Trigo (CIMMYT), La Frailesca, Mexico. 2017.

Cuadro 2. Efectos de la cal dolomítica sobre el $\mathrm{pH}_{\mathrm{Ca}}$, el Ca y el $\mathrm{Mg}$ intercambiables y los porcentaje de saturación de Ca y Al, a dos profundidades de suelo en las localidades Edray y Francisco. Instituto Nacional de Investigaciones Forestales, Agrícolas y Pecuarias (INIFAP), Centro Internacional de Mejoramiento de Maíz y Trigo (CIMMYT), en La Frailesca, México. 2017.

\begin{tabular}{|c|c|c|c|c|c|c|c|c|c|c|}
\hline \multirow{3}{*}{$\begin{array}{l}\text { depth } \\
(\mathrm{cm})\end{array}$} & \multicolumn{5}{|c|}{ Edray } & \multicolumn{5}{|c|}{ Francisco } \\
\hline & \multirow[b]{2}{*}{$\mathbf{p H}_{\mathrm{Ca}}{ }^{1}$} & \multicolumn{2}{|c|}{$\left(\mathrm{cmol}_{\mathrm{c}} \mathrm{kg}^{-1}\right)$} & \multirow[b]{2}{*}{$\mathrm{Ca}(\%)$} & \multirow[b]{2}{*}{$\operatorname{Al}(\%)$} & \multirow[b]{2}{*}{$\mathrm{pH}_{\mathrm{Ca}}{ }^{1}$} & \multicolumn{2}{|c|}{$\left(\mathrm{cmol}_{\mathrm{c}} \mathrm{kg}^{-1}\right)$} & \multirow[b]{2}{*}{$\mathrm{Ca}(\%)$} & \multirow[b]{2}{*}{$\operatorname{Al}(\%)$} \\
\hline & & $\mathrm{Ca}$ & $\mathrm{Mg}$ & & & & $\mathbf{C a}$ & Mg & & \\
\hline $0-7.5$ & 4.1 & 1.5 & 0.56 & 57 & 11 & 4.4 & 2.4 & 0.92 & 65 & 4 \\
\hline $7.5-15$ & 3.6 & 0.8 & 0.25 & 32 & 46 & 3.7 & 1.5 & 0.55 & 48 & 27 \\
\hline $\mathrm{LSD}_{5 \%}$ & 0.2 & 0.3 & 0.06 & 7 & 7 & 0.2 & 1.5 & 0.13 & 6 & 6 \\
\hline
\end{tabular}

${ }^{1} \mathrm{pH}_{\mathrm{Ca}}: \mathrm{pH}$ measured in $0.01 \mathrm{M} \mathrm{CaCl}_{2} \cdot /{ }^{1} \mathrm{pH}_{\mathrm{Ca}}: \mathrm{pH}$ medido en $0,01 \mathrm{M} \mathrm{CaCl}_{2}$.

\section{Discussion}

Maize yield responded positively to $\mathrm{K}$ and gypsum application (Figures 1 and 2) as could be expected by the locations' low initial soil $\mathrm{K}$ and Ca contents (Table 1). However, the effects on yields observed in location Hermilo differed from the other locations: less $\mathrm{K}$ and more gypsum were needed to reach the plateau, probably because its soil had the highest initial soil $\mathrm{K}$ and a lower initial soil Ca contents (Table 1).

The effects of $\mathrm{K}$ application on maize yields can be related to the higher soil exchangeable $\mathrm{K}$ measured in the soil at the end of the 2017 crop cycle (Figure 3). The absence of crop response after $70 \mathrm{~kg} \mathrm{ha}^{-1} \mathrm{of} \mathrm{K}_{2} \mathrm{O}$ in location Hermilo, and $120 \mathrm{~kg} \mathrm{ha}^{-1}$ of $\mathrm{K}_{2} \mathrm{O}$, in the remainder locations, is indicative of other yield limiting factors.

At both locations in 2017, soil exchangeable Ca augmented in the top $15 \mathrm{~cm}$ of soil, and although the greatest increase was observed at the upper $7.5 \mathrm{~cm}$, these results suggest that at least part of the gypsum moved between the upper 7.5 and $15 \mathrm{~cm}$. This might have been related to the high rainfall in 2017, since faster responses, associated with greater S and Ca availability, have also been reported for areas of high pluviosity in Brazil (Sumner, 1993). Nevertheless, the limited effects of gypsum at greater depths, in spite of the abundant rain received in 2017, point out to factors that slow down its effectiveness such as it not being mixed into the soil and the reported slow dissolution of mine gypsum in water (Shainberg et al., 1989; Sumner, 1993). Also, adsorption of $\mathrm{SO}_{4}^{-2}$ to soil colloids retards its leaching (Borkert et al., 1987). This process might be important in the soils under study since preliminary soil characterization using the procedure described by Sumner (1990) has shown ((A Tasistro, personal communication, 2014)) that soils in La Frailesca were responsive to gypsum.

Gypsum can also boost crop yields through the reduction of exchangeable Al (Shainberg et al., 1989; Sumner, 1990; 1993). Although gypsum decreased Al saturation in the upper $7.5 \mathrm{~cm}$ of the soil in location Edray (Figure 5) the range of Al saturation values in which the response was observed $(<12 \%)$ was below the $25 \%$ critical level for maize (Espinosa \& Molina, 1999). These low values of Al saturation were the result of the lime application made to all the experimental area prior to the beginning of the study. Thus, it is unlikely that the effect of gypsum on $\mathrm{Al}$ was associated with the crop yield response.

Gypsum does not neutralize or form acids so its reported effects on soil $\mathrm{pH}$ are typically small - in the order of 0.2-0.3 pH units - including both increases and decreases. Effects such as the increases shown in Figure 6 may result from the interaction of several mechanisms: the balance between $\mathrm{H}^{+}$and $\mathrm{Al}^{+3}$ (which can hydrolyze and 
release $\mathrm{H}^{+}$) exchanged for $\mathrm{Ca}^{+2}$, and $\mathrm{OH}^{-}$exchanged for $\mathrm{SO}_{4}^{-2}$, soil heterogeneity, and problems associated with sampling (Borkert et al., 1987; Sumner, 1993; Zoca \& Penn, 2017). Any of those mechanisms could have acted in the present case, plus an additional one related to the presence of carbonates as impurities, unfortunately non quantified in the gypsum used, which are common in natural gypsum deposits (Zoca \& Penn, 2017).

Together, the responses of maize yield to gypsum and to soil exchangeable $\mathrm{Ca}$ and $\mathrm{pH}$, suggest that the latter maybe limiting at gypsum rates lower than $1.25 \mathrm{t} \mathrm{ha}^{-1}$ in locations Raquel, Edray and Francisco, and $3 \mathrm{t} \mathrm{ha}^{-1}$ in location Hermilo. At higher gypsum rates, maize yield reached a plateau, while soil exchangeable $\mathrm{Ca}$ and $\mathrm{pH}$ kept increasing, a situation indicative of other more important yield limiting conditions.

The blanket application of dolomitic lime worked as intended: it increased $\mathrm{pH}$ and exchangeable $\mathrm{Ca}$ and $\mathrm{Mg}$ contents and lowered $\mathrm{Al}$ content in the top $7.5 \mathrm{~cm}$ of soil compared to the 7.5-15 cm depth (Table 2). Moreover, these results indicate that lime was effectively mixed in the top $7.5 \mathrm{~cm}$, which is about $2 / 3$ of the working depth $(10-12 \mathrm{~cm})$ of the disk harrow used to incorporate into the soil after its application. This depth is greater than the $1 / 3$ of the working depth of the implement that Beegle (1996) considered as a standard, probably because two passes were made.

However, despite its increase, the $\mathrm{pH}$ remained in the low range. This could be explained because the effect of limestone as a corrective of acidity can be reduced if it is applied jointly with gypsum, since the latter saturates the soil solution with calcium, decreasing the speed of the calcium carbonate hydrolysis reaction (Borkert et al., 1987). One study recommend that lime be applied early enough before gypsum (60-90 days) in order to provide optimal moisture conditions for the reaction between the lime and soil particles (Borkert et al., 1987). This interval is much longer than what was followed in the present study.

\section{Conclusions}

Maize growing in soils with less than 0.3 and $1.9 \mathrm{cmol}_{\mathrm{c}} \mathrm{kg}^{-1}$ of $\mathrm{K}$ and $\mathrm{Ca}$, respectively, responded to $\mathrm{K}$ and gypsum. The effects of the latter were probably associated to its supplying $\mathrm{Ca}$, although the addition of $\mathrm{S}$ may have also been important.

The beneficial effects on grain yield of liming showed in the top $7.5 \mathrm{~cm}$ of soil through decreased $\mathrm{Al}$ saturation, and increased $\mathrm{pH}$, and $\mathrm{Ca}$ and $\mathrm{Mg}$ contents. At the end of the first crop cycle after application and in spite of the favorable moisture conditions, the effects from gypsum were mostly confined also to the top $7.5 \mathrm{~cm}$ of soil.

The increase in soil $\mathrm{K}$ and $\mathrm{Ca}$ in such a shallow depth was sufficient to bring about positive responses from the crop because the rainfall during the study period was very favorable. The situation might have been different under dryer conditions when the roots would have been limited in obtaining water from deeper layers because of their higher Al saturation.

Longer term evaluations are needed to determine the evolution of the effects of gypsum on characteristics deeper in the soil under more varied climatic conditions.

\section{References}

Beegle, D. (1996). Nutrient management in conservation tillage systems. Pennsylvania State University. https://extension.psu. edu/nutrient-management-in-conservation-tillage-systems

Borkert, C. M., Pavan, M.A., \& Lantmann, Á. F. (1987). Considerações sobre o uso de gesso na agricultura. Empresa Brasileira de Pesquisa Agropecuária. https://docplayer.com.br/20119738-Consideracoes-sobre-o-uso-de-gesso-na-agricultura. html 
Buerkert, A., Cassman, K. G., de la Piedra, R., \& Munns, D. N. (1990). Soil acidity and liming effects on stand, nodulation, and yield of common bean. Agronomy Journal, 82, 749-754. https://doi.org/10.2134/agronj1990.00021962008200040020x

Castellanos-Ramos, J. Z., Cueto-Wong, J. A., Macías-Cervantes, J., Salinas-García, J. R., Tapia-Vargas, L. M., Cortés-Jiménez, J. M., González-Acuña, I. J., Mata-Vázquez, H., Mora-Gutiérrez, M., Vásquez-Hernández, A., Valenzuela-Solano, C., \& Enríquez-Reyes, S. A. (2005). La fertilización en los cultivos de maíz, sorgo y trigo en México. Instituto Nacional de Investigaciones Forestales, Agrícolas y Pecuarias.

Espinosa, J., \& Molina, E. (1999). Acidez y encalado de los suelos (1ª Ed.). International Plant Nutrition Institute.

Hibon, A., Triomphe, B., Lopez-Pereira, M. A., \& Saad, L. (1992). Rainfed maize production in Mexico: Trends, constraints, and technological and institutional challenges for researchers. Centro Internacional de Mejoramiento de Maíz y Trigo. https://repository.cimmyt.org/xmlui/bitstream/handle/10883/884/38481.pdf

Knudsen, D., Peterson, G. A., \& Pratt, P. F. (1982). Lithium, sodium, and potassium. In A. L. Page, R. H. Miller, \& D. R. Keeney (Eds.), Methods of soil analysis. Part 2. (2 $2^{\text {nd }}$ Ed., pp. 225-246). American Society of Agronomy, \& Soil Science Society of America.

Lin, C., \& Coleman, N. T. (1960). The measurement of exchangeable aluminum in soils and clays. Soil Science Society of America Journal, 24(6), 444-446. https://doi.org/10.2136/sssaj1960.03615995002400060009x

López-Báez, W., Reynoso-Santos, R., López-Martínez, J., Villar-Sánchez, B., Camas-Gómez, R., \& García-Santiago, J. O. (2019). Caracterización físico-química de suelos cultivados con maíz en Villaflores, Chiapas. Revista Mexicana de Ciencias Agrícolas, 10, 897-910. https://doi.org/10.29312/remexca.v10i4.1764

Serrano, A. V., M.A., Díaz-Padilla, G., López-Luna, A., Cano-García, M.A., Báez-González,A. D., \& Garrido-Ramírez, E. R. (2006). Estadísticas climatológicas básicas del Estado de Chiapas (Período 1961-2003). Instituto Nacional de Investigaciones Forestales, Agrícolas y Pecuarias, \& Secretaría de Agricultura, Ganadería, Desarrollo Rural, Pesca y Alimentación.

Shainberg, I., Sumner, M. E., Miller, W. P., Farina, M. P. W., Pavan, M. A., \& Fey, M. V. (1989). Use of gypsum on soils. A review. In B. A. Stewart (Ed.), Advances in Soil Science (Vol. 9, pp. 1-110). Springer Verlag.

Soil Survey Staff (Ed.). (2014). Illustrated guide to soil taxonomy. United States Department of Agriculture, Natural Resources Conservation Service, \& National Soil Survey Center. https://nrcspad.sc.egov.usda.gov/DistributionCenter/pdf. aspx?productID=1096

Sumner, M. E. (1990). Gypsum as an ameliorant for the subsoil acidity syndrome. Florida Institute of Phosphate Research.

Sumner, M. E. (1993). Gypsum and acid soils: The world scene. In D. L. Sparks (Ed.), Advances in Agronomy (Vol. 51, pp. 1-32). Academic Press. https://doi.org/10.1016/S0065-2113(08)60589-1

Tasistro, A., \& Camas-Gómez, R. (2015). Enmiendas para controlar la acidez del suelo y del subsuelo y su interacción con potasio. In C. Loredo-Osti, J. L. Lara-Mireles, S. Beltrán-López, \& R. D. V. Cepeda (Eds.), Memorias del XL Congreso Nacional de la Ciencia del Suelo - Simposio: Avances Sobre Fertilidad de Suelos en México (pp. 10491053). Sociedad Mexicana de la Ciencia del Suelo.

Van Raij, B. (2008). Gesso na Agricultura. Informações Agronómicas, 122(Junho), 26-27.

VSN International. (2018). Genstat for Windows - Version 19.1. VSN International.

Zoca, S. M., \& Penn, C. (2017). An important tool with no instruction manual: A review of gypsum use in agriculture. In D. L. Sparks (Ed.), Advances in Agronomy (Chap. 1, Vol. 144, pp. 1-44). Academic Press. https://doi.org/10.1016/ bs.agron.2017.03.001 